\title{
Looking for a dialogue between farmers and scientific soil knowledge: Learnings from an ethno-geomorphopedological study in a Philippine's upland village
}

\author{
Lola Richelle (iD), Marjolein Visser ${ }^{\mathrm{b}}$, Laurent Bockc, Peter Walpoled, \\ François Mialhe $\left(\mathbb{D}^{\mathrm{a}} \mathrm{e}\right.$, Gilles Colinet ${ }^{\mathrm{f}}$, and Nicolas Dendoncker (D) $^{\mathrm{a}}$
}

aDepartment of Geography, University of Namur, Namur, Belgium; bLandscape Ecology Laboratory, University of Brussels (ULB), Bruxelles, Belgium; 'Department of Environmental Sciences and Technologies, University of Liege-Gembloux Agro-Bio Tech, Unity of Soil Science, Gembloux, Belgium; 'Environmental Science for Social Change (ESSC), Malaybalay City, Bukidnoon, Philippines; eDepartment of Geography, University of Lyon, Lyon, France; fWater, Soil \& Plant Exchanges, BIOSystem Engineering, Gembloux Agro Bio Tech, University of Liège, Gembloux, Belgium

\begin{abstract}
Several ethnopedological studies highlight the plurality of soil knowledge and the complexity of soil knowledge systems. These knowledge systems are specific to social groups or communities and the dialogue between them is not easy. Local soil knowledge is often misrepresented and reduced when correspondences with soil sciences categories are established without due care.

This paper results from two field studies in an upland village of Southern Philippines. The sociocultural richness and the high diversity of farming systems characterizing this local context have highlighted the importance of accounting for the diversity of soil knowledge related to local issues and sustainability. Looking for a dialogue among the plurality of perceptions, knowledge system, and typologies regarding soils implies that attention be given to knowledge construction processes. In order to facilitate an egalitarian dialogue it is also essential to explore relations between soil knowledge, farming systems, and sociocultural context.

Discussion with farmers about their soils has cast doubt on the practical relevance of soil science knowledge in a context of non-industrial and non-chemical agriculture and revealed the dynamic dimension of farmers' soil knowledge construction and the practical relevance of contextualized knowledge.

In this paper, we propose methodological and epistemological thoughts to help establish a common language between scientists and farmers. We also propose to use the soil groups emerging from field characterization as a practical tool to dialogue with farmers in the field, to build a common understanding of soil heterogeneity. We consider this approach as a critical step to initiate collaborative soil studies from a practical and endogenous perspective.
\end{abstract}

\section{KEYWORDS}

Collaborative research; ethnopedology; indigenous and farmers knowledge; soil typologies; upland context

CONTACT Lola Richelle lola.richelle@unamur.be Department of Geography, University of Namur, 61 rue de Bruxelles, 5000 Namur, Belgium.

Color versions of one or more of the figures in the article can be found online at www.tandfonline.com/wjsa. 


\section{Introduction}

Philippine's upland context is characterized by the coexistence of several cultures and farming practices: ancestral practices and nature's perceptions rub shoulders with some of the most recent agricultural technologies like genetically modified organisms (GMO). Such "cohabitation" is a rich source of diversity but also of conflict. It highlights the necessity to consider the diversity of farming knowledge, agricultural models, and ecological and cultural consequences of their interaction, in order to strengthen sustainable farming practices and endogenous perspectives.

Farming systems evolve in relation to specific biophysical contexts and local human realities. The diversity of farming practices is a social and cultural wealth and each context deserves a particular attention. However, mechanization, international agro-industries, and new technologies tend to homogenize agricultural production and consumption, without taking into account local contexts' particularities and the importance of cultural and biological diversity (Pretty et al. 2009; Shiva 1993). In rural development projects and agronomical studies, local people's points of view and knowledge are most often neglected, and modern scientific knowledge is imposed as the only valid one (Howard 1994; WinklerPrins 1999). When interest in local knowledge is shown, it often aims to involve local people in imported development projects without paying attention to endogenous perspectives (Agrawal 1995). Indigenous highland people are among the most affected by this logic of homogenization because their singular ways of life are threatened by abrupt changes in land use, agricultural techniques, and cultural behaviors (Karl and Gaspard 2000).

Soil studies are part of this process: the way soils are studied informs the way agronomical advice is conceived and leads to changes in cropping practices. The recommendations made by soil experts cannot adequately match local biophysical and human realities if they are disconnected from endogenous farming dynamics. The adoption of imported farming practices emerging from or encouraged by these recommendations may finally lead to the degradation of local environments (e.g., soil erosion, loss of organic matter, and water contamination).

Recognizing the singularity of local knowledge is essential to avoid bypassing the contextual complexity of knowledge diversity. It is also an ethical imperative.

Scientific knowledge as vernacular knowledge is culturally embedded (Stevenson 1996). However, as anthropologists like Sillitoe (1998) cited in Barrera-Bassols (2010) argue, they differ in the way they are constructed: local knowledge is mainly based on observations and highly contextual, while scientific knowledge is more abstract and purports to be universal. Other authors like Toledo (1991) argue that, in the context of Ethnoecology, taking into account these differences implies to consider beliefs, perceptions, and knowledge as three intellectual operations used by local people in their practical appropriation of ecosystems. Local knowledge results from and contributes to a dynamic 
interaction between living processes and human sociocultural history (Toledo and Barrera-Bassols 2008). This means that local knowledge cannot simply be abstracted from its socioecological context. It cannot be compared objectively to rational scientific knowledge without distorting its meanings and depriving it of its practical dimension. In order to not destroy and/or improve farmers' livelihoods, it is crucial to work with them and to learn from their contextualized knowledge.

Most studies on local soil knowledge focus on vernacular typologies. However, several of these studies merely aim to connect vernacular typologies to modern scientific knowledge and soil classification without interest for the practical dimension of this knowledge. Other studies, taking a more practical perspective, show that vernacular typologies can be useful for improving the quality of research projects focusing on farming land use planning (Henquin et al. 1991; Krasilnikov and Tabor 2003; Niemeijer and Mazzucato 2003; Payton et al. 2003; Rushemuka et al. 2014; Saito et al. 2006). Nevertheless, more attention should be given to establishing an egalitarian dialogue in order to avoid homogenization of soil knowledge. Indeed, the interdependence between knowledge and practices in agriculture implies that homogenization of soil knowledge risks contributing to the homogenization in farming practices (and vice versa). Likewise, homogenization of farming practices is linked to a loss of sociocultural diversity in rural areas.

As stated by Ramisch (2014), a dialogue between different types of knowledge generates epistemological and political challenges. Understanding dissonances and power relationships between types of knowledge is a prerequisite to associating them in a complementary perspective.

This paper aims to contribute to methodological and epistemological thinking about soil knowledge diversity and relationships between knowledge and practice in agriculture. The immersion into the daily life of local people determined the orientation of the epistemological discussion presented here. We focus on vernacular soil typologies, insisting on the practical relation between soil typologies and cropping practices. We structured this study along three main axes; a geomorphopedological survey, an ethnopedological approach, and a discussion about knowledge and practical issues concerning the confrontation between the first and the second topics.

The epistemological objective of this study is to contribute to the understanding of similarities and differences between soil knowledge systems with a comparative analysis of three ways to grasp and describe soil heterogeneity (vernacular typologies, field based identification, and the FAO World Reference Base (WRB) classification). The comparative analysis is structured by the identification, for each of the three approaches, of knowledge construction processes, purposes of knowledge, context, and specificity of soil description. The discussion is guided by three questions: How do descriptions of soil heterogeneity differ? Are vernacular typologies and scientific classification compatible? To which farming practices and ways of living do they relate? 
The methodological and practical objective of this paper is to contribute to the dialogue between scientists and farmers in terms of understanding soil heterogeneity, based on a case study in the Southern Philippines. We propose to use the soils groups emerging from field characterization as a practical tool to work with farmers in the field in order to build a common understanding of soil heterogeneity. We argue that these soil groups (SG), locally situated, can serve as a bridge to foster dialogue between local and scientific approaches of soil heterogeneity, contextualizing in this way soil knowledge in a more practical perspective.

\section{Materials and methods}

The field survey consisted of two main phases: (I) The first part was a classical soil study based on a geomorphopedological approach (Bock 1994), with an interest in vernacular soil typologies. (II) Having failed to communicate the scientific results of this first phase to local people, we decided to conduct the second phase of the study to try and bridge the gap between scientific and vernacular knowledge and to explore ways of generating knowledge on soils that are relevant for practice. The second part of the study was inspired by ethnopedological perspectives (Barrera-Bassols and Zinck 2003) in order to complete the geomorphopedological approach by highlighting and deepening the human dimension. In this new focus of the study, the survey was mainly dedicated to cultural and personal aspects of every day soil-human relationship.

\section{Study site}

This study focuses on one village, Bendum, and its catchment, concentrating research efforts on a micro-local scale in order to explore the complexity of this particular situation and to have time to share the daily lives of local people. Furthermore, the high soil heterogeneity in this mountainous area, the cultural diversity of this region, and the absence of roads limited the possibilities of exploring a wider area in the time given to this study. This scale of study allows a better understanding of the interactions and discrepancies between human livelihoods and natural processes in terms of soils characteristics, soils uses, and local knowledge.

The study area is located in the southern Philippines in Mindanao Island (Figure 1). It is part of Upper Pulangi watershed in the northeast of Bukidnon province $\left(7^{\circ} 21-8^{\circ} 35^{\prime} \mathrm{N}, 124^{\circ} 33^{\prime}-125^{\circ} 26^{\prime} \mathrm{E}\right)$. The study site is situated at $750 \mathrm{~m}$ above sea level in the uplands of Pantaron Mountain Range (Central Cordillera) on the east slope of the Pulangi River. Slopes are mostly steep (>18\%) but the village is built on an undulated plateau where slopes are moderate. Elevation ranges from 550 (Pulangi valley) to 1400 (local summit) meters high. Climatic conditions are those of the humid tropics without any marked dry season. 


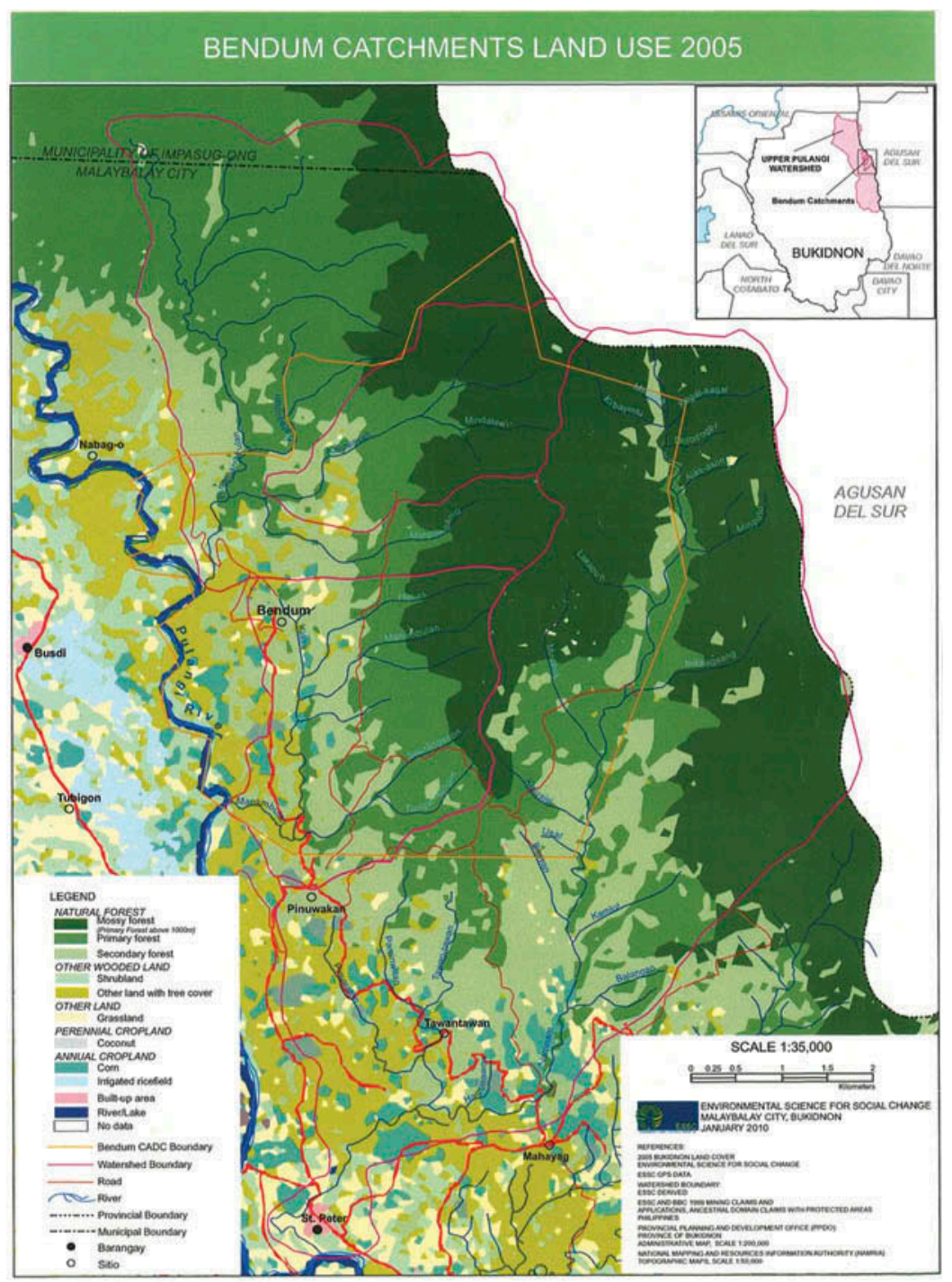

Figure 1. Bendum catchments land use 2005, in Upper Pulangi watershed, Bukidnon Province (ESSC 2010).

Annual rainfall ranges from $2340 \mathrm{~mm}$ to $4000 \mathrm{~mm}$. The rainiest period is between December and February. Temperatures are under the national average $\left(26.6^{\circ} \mathrm{C}\right.$ at sea level) because of the elevation.

The geomorphology of Bukidnon province and study area results from a complex geological history whose principal agents are diastrophic evolution of earth crust, lacustrine and sub-marine sedimentation, volcanic eruption, reef formation, and continuous erosion. The Central Cordillera results predominantly from tectonic movements and is constituted of sedimentary, magmatic, and metamorphic rocks (Bureau of Soils 1985). The study area's geology is more particularly constituted by a layer of green shale and ultrabasic complex covered 
by volcanic lava and ash and by a sedimentary rock sequence (Walpole 2002). The presence of active faults causes relatively frequent strong earthquakes and also involves a complex hydrographic system. Water resources are abundant in this region because of intense rainfall creating numerous streams along mountain slopes and drained by the Pulangi River. The village area is drained by several mountain streams, but mainly by Pinamangkulan and Manambulan, both direct tributaries of the Pulangi.

Originally, as for the entire Philippines archipelago, the vegetation consisted of a dense tropical forest with a rich biodiversity (Whitford 1911). In Bukidnon province, $49 \%$ of uplands have lost their forest cover. Some fragments of primary forest still remain on the upper ridges and steepest slopes. Bendum village stands at the edge of one of these last patches of primary forests. Below this limit (800 m contour line), the forest was cut between 1976 and 1980 by logging companies without any attention for people living in it (Walpole 2002; Walpole et al. 1993). Our study site is mainly covered by forested area and small polyculture farms. In Bukidnon province, land use today consists mainly of monocultures of corn, rubber, irrigated rice, sugarcane, and pineapple.

Bendum village comprises around 300 inhabitants. It is remotely located in the mountains with no paved road to join it. Government infrastructure is nearly absent, and the connection with the electricity grid only occurred in 2011. Public infrastructures mainly stem from nongovernmental organization initiatives such as Environmental Sciences for Social Change (ESSC) (Anonym 2005). People who have been living there for several generations are named Pulangiyen (or Lumad in a more generic term). In their tradition, forests and natural elements are inhabited by spirits, but they consider it legitimate to live in this domain because their ancestors lived there and performed rituals in some sacred areas. Indeed, as humans are not the owners of the land or of the natural elements, they need to accomplish several rituals to ask the permission of these spirits to borrow land or use natural elements (Bendum Tribal Council, 2002).

The proximity of the forest is important for the Bendum community, not only for environmental concerns including air and water quality but also and mainly for the livelihoods of the Pulangiyen people who rely on it for hunting, gathering and its spiritual dimension (Lawrence 1995), and also during drought for emergency foods. Some migrants (Dumagat) who arrived in the eighties from others Philippine provinces to look for land are now part of the community. Even though land ownership and access issues are not resolved, Dumagat and Pulangyen have found a way to coexist.

With regards to agriculture and food, there is a large diversity of farming practices, from those coming from Lumad traditional way of life ("kaigin": swidden agriculture) to more industrial cultivation methods imported from the lowlands by migrants. However, mechanization is absent and great crop diversity can still be found. Subsistence agriculture based on root crops, fruit trees, and some cereals (rice, jobs tears, corn), is still strongly present, sometimes 
combined with cash crops (abaca: Musa textilis, coffee, rubber, corn, ginger). A decade ago more farmers began to use non-indigenous varieties and seeds (e.g., hybrid and GMO corn, rubber), and external inputs (chemical fertilizers, pesticides, and herbicide). Consequently, over the last two decades, areas dedicated to monoculture expanded over polyculture, disturbing the balance of this socioagroecosystem.

\section{Soil survey}

Very few investigations on soils have been conducted in this forest frontier area and there is almost no published information. Existing soil maps (Alcasid et Godofredo, 1995; FAO 1975) are not precise enough to help in fieldwork. The soil map of Bukidnon province (Mariano 1950, 1955) uses the terms "mountain soils" without any further details. This study should be considered as exploratory.

\section{Geomorphopedological approach}

Field observations. A three-month soil survey was conducted in 2010 applying a geomorphopedological approach in order to assess soil heterogeneity in relation to landscape and land use in this catchment. After an initial attention to maps (geological, pedological, and topographical), landscape topography, lithological outcrops, natural vegetation, and land use, soils were observed first by regular augering along two complementary toposequences. People of Bendum acted as guides throughout the fieldwork. Their presence and knowledge about local environment were a valuable help. Toposequences were localized in order to cover the catchment's main topographical features with an overlap in the cultivated area to match the agricultural focus of this study (Figure 2). To make up for the lack of appropriate maps, streams and river were taken as landmarks, as local people do.

The main SG identified were studied in more detail by adding a complete description of soil profiles (soil pit $1 \mathrm{~m}^{2}$ and $1.20 \mathrm{~m}$ deep). For all 25 augerings and 13 soil profiles, site characteristics were described following methods of Delecour and Kindermans (1980) and FAO (2006b). Soil characteristics observed in the field (augerings and profiles) were soil horizons and depth, color, texture, structure, porosity, compaction, $\mathrm{pH}$ (by color $\mathrm{pH}$ kit) and the nature and properties of stones and mottles. Composite samples of the surface layer (0-20 cm depth) were also gathered in order to assess soil chemical status through laboratory analyses. In total, 33 composite samples were collected by picking up 12 samples in a circle of $5 \mathrm{~m}$ radius around the augering or center of soil pit and mixing these thoroughly.

Chemical assessment and analytical methods. Laboratory analyses were conducted and interpreted for each of the SG identified during fieldwork. On the 


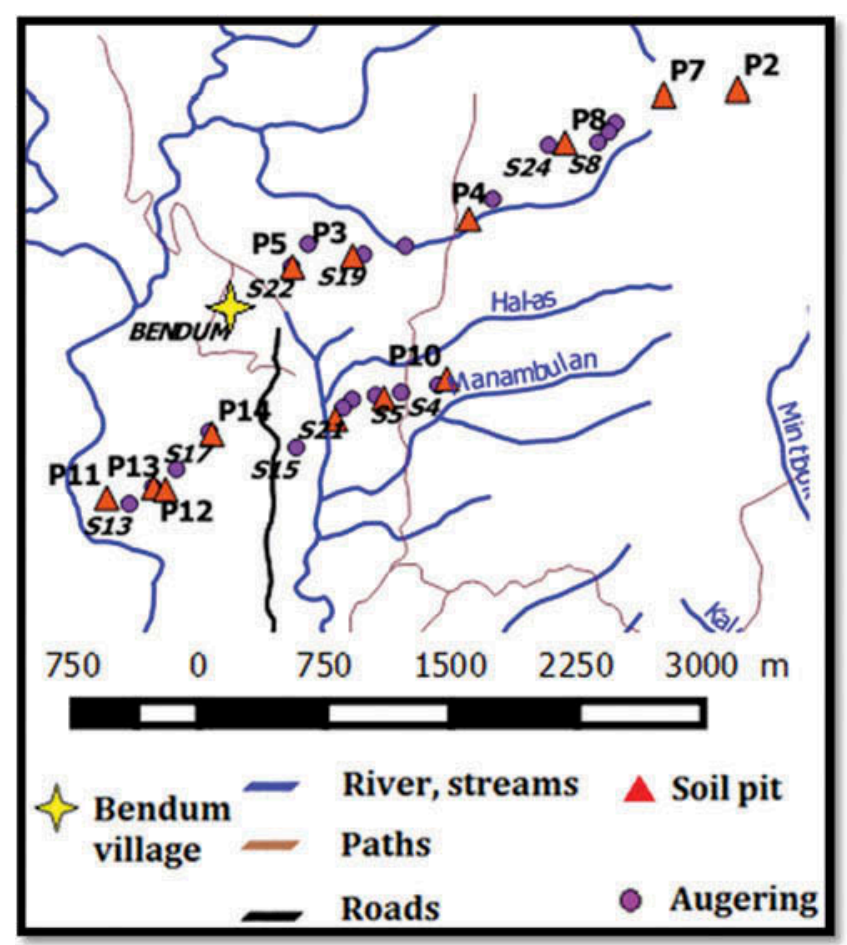

Figure 2. Location of soil observations in Bendum catchment (2 toposequences).

composite samples, parameters analyzed were $\mathrm{pH}$, Total Organic Carbon (TOC), Total Nitrogen (NT) and available nutrients ( $\mathrm{Ca}, \mathrm{Mg}, \mathrm{K}$ and $\mathrm{P}$ ). For samples that had a $\mathrm{pH} \mathrm{KCl}$ inferior or equal to 5, exchangeable acidity and aluminum were also analyzed. Laboratory protocol followed that of Colinet et al. (2011).

\section{Soil classification and typologies}

The soils described were grouped according to common characteristics observed in the field. Topographical position of each soil observation was determinant to define SG.

The SG identified were related to the FAO WRB classification (FAO 2006a) when achievable with field observations. The WRB classification is based on horizon, materials, and properties of diagnosis which can be partially observed in the field. However, to establish a relation with soil classes from WRB classification with certainty, further information such as particular chemical criteria and specific laboratory analyses are required (grain size distribution, clay mineralogy, cation exchange capacity (CEC) at $\mathrm{pH} 7$, extractable $\mathrm{Fe}$, etc.). We did not perform these investigations because it was not the priority of the study. 


\section{Community survey: agricultural practices and farmers' knowledge on soils}

Inspired from the ethnopedological framework based on the KPC complex (Kosmos, Corpus, and Praxis) (Barrera-Bassols, Zinck, and Van Ranst 2006), the idea was to contribute to the understanding of the articulation between beliefs, knowledge, and uses related to soils.

Bendum villagers were involved in the soil survey in two complementary ways. First, in order to better understand their concerns about soils, villagers were interviewed on their knowledge and the criteria they applied to evaluate soils. Secondly, an attempt was made to facilitate their understanding of the scientific survey in order to initiate a better sharing of knowledge. This part of the research mainly consisted of qualitative semi-structured interviews and community meetings, carried out within two distinct timeframes.

During the first stay in the village (March 2010), collective meetings were held with villagers concerning the village history, beliefs and perceptions of the natural environment, and vernacular knowledge about soils. A first draft of vernacular typologies resulted from these meetings. Other interviews, at the household level, were carried out in the fields in order to gather practical information from farmers concerning the sampled plots presented in the previous section. Six farm households were interviewed about their practices, crop rotations, and plot history. During the second stay in the village (December 2011), the research focused on vernacular perceptions and knowledge about soil, in order to compare the geomorphopedological results to the knowledge and understanding of local people. A feedback was given to the six couples interviewed previously and eleven other farm households were interviewed about their farming practices, and representations and knowledge about soil. People interviewed were chosen in order to capture as far as possible a qualitative scope of the diversity of situations according to the following criteria: cropping system, crop diversity and varieties, dominance of cash crop or food crop, animal or human traction, location and slope of the land, ethnicity origin and age.

Two methodological steps were further implemented to gain a more complete understanding of soil typologies. First, a table was drawn with two key informants (one from Pulangiyen people and the other from Visayas islands origin) and, second, interviews were conducted at the household level asking households to describe and name soil types present in their land. Two distinctive typologies were formulated, one in Pinulangiyen or generically termed Binukid (language of Pulangiyen people) and the other in Bisaya (language of migrants coming from Visayas islands). All discussions and interviews were made with help of a local translator (working with ESSC). Shifting from one language to another was not easy and some notions and subtleties were inevitably lost. Interviews lasted about 2 hours. 


\section{Results}

\section{Geomorphopedological characterization}

\section{Toposequencial approach}

Topographically, the study area comprises three main land units consisting of intricate combinations of the elevation, morphology, geology, and land cover. These three main land units were taken as the basic framework to further investigate soil heterogeneity (Figure 3).

The upper slope (Unit 1) is a forested area characterized by steep slopes $(>18 \%)$ and dense primary forest. Geology is dominated by ultrabasic intrusive rocks. The vegetation changes along a vertical gradient (e.g., the presence of moss increases strongly from $1100 \mathrm{~m}$ height to the summit $(1400 \mathrm{~m})$ ). In this unit, seven augerings and five soil profiles (pits) were completed.

The second land unit (Unit 2), at the village altitude, is an undulating area where most of forest land has been cleared and cultivated. It is characterized by long gentle slopes, some short steep slopes, and a geology dominated by volcanic agglomerates. A high number of augerings (thirteen) and soil profiles (four) were realized in this land unit because it is mainly dedicated to agriculture. This unit is covered by a mosaic of fields, herbaceous or woody fallows, and grassland. Crops are corn, coffee, rubber, ginger, abaca, banana tree, irrigated rice, cassava, taro and job's tears, and can be grown mixed or in monoculture. Both toposequences cover this unit.

Unit 3 is located in the vicinity of the river and encompasses both steep forested slopes and cultivated river banks. Geology is dominated by volcanic agglomerates, sandstones, and shale. Most of this unit is covered by ligneous vegetation; indeed steep slopes $(>20 \%)$ do not allow cultivation. Some small flat areas are farmed. The main crop is corn, but there are also small plots of sweet potatoes and fruit trees. Along the river some root crops are cultivated. This unit is characterized by its hilly topography that generates a high heterogeneity. In this unit four augerings and three soil profiles were completed.

\section{Pedological characterization}

Soil groups identification. The toposequencial approach allows defining 12 sub-units based on elevation, vegetation, and soil changes (four in Unit 1, five in Unit 2 and three in Unit 3). These sub-units serve as a more detailed framework for describing local soil heterogeneity. Each soil group is related to one sub-unit. Table 1 presents details of characterization for each soil group.

The level of heterogeneity is a matter of scale. At a micro-local scale, the study area presents high soil heterogeneity. Nevertheless these soils share common general characteristics such as clayey-loam dominant texture, strong acidity (at least in the topsoil), deficiency of available phosphorus, and low available cation content. 

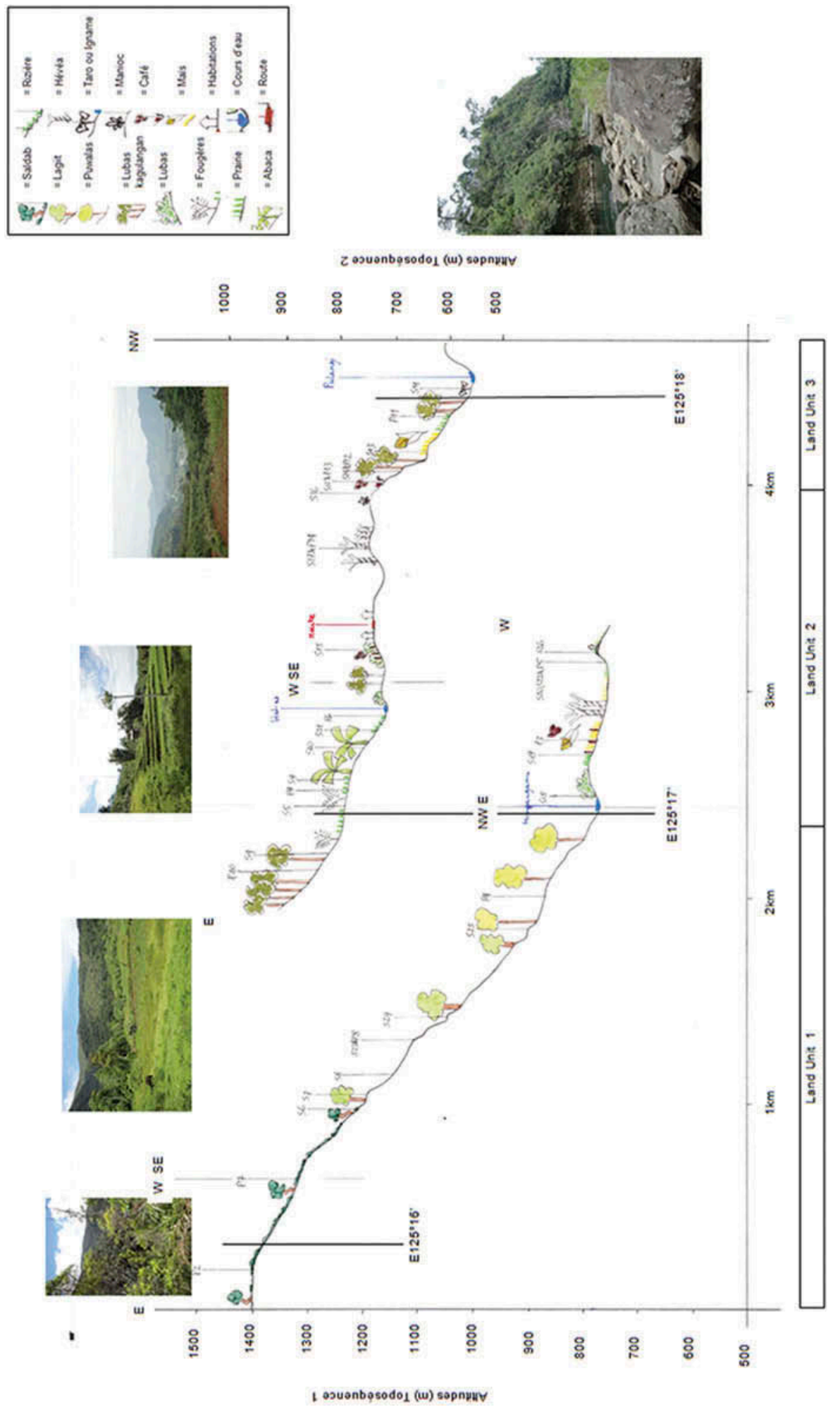

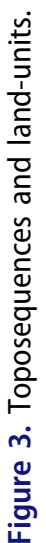




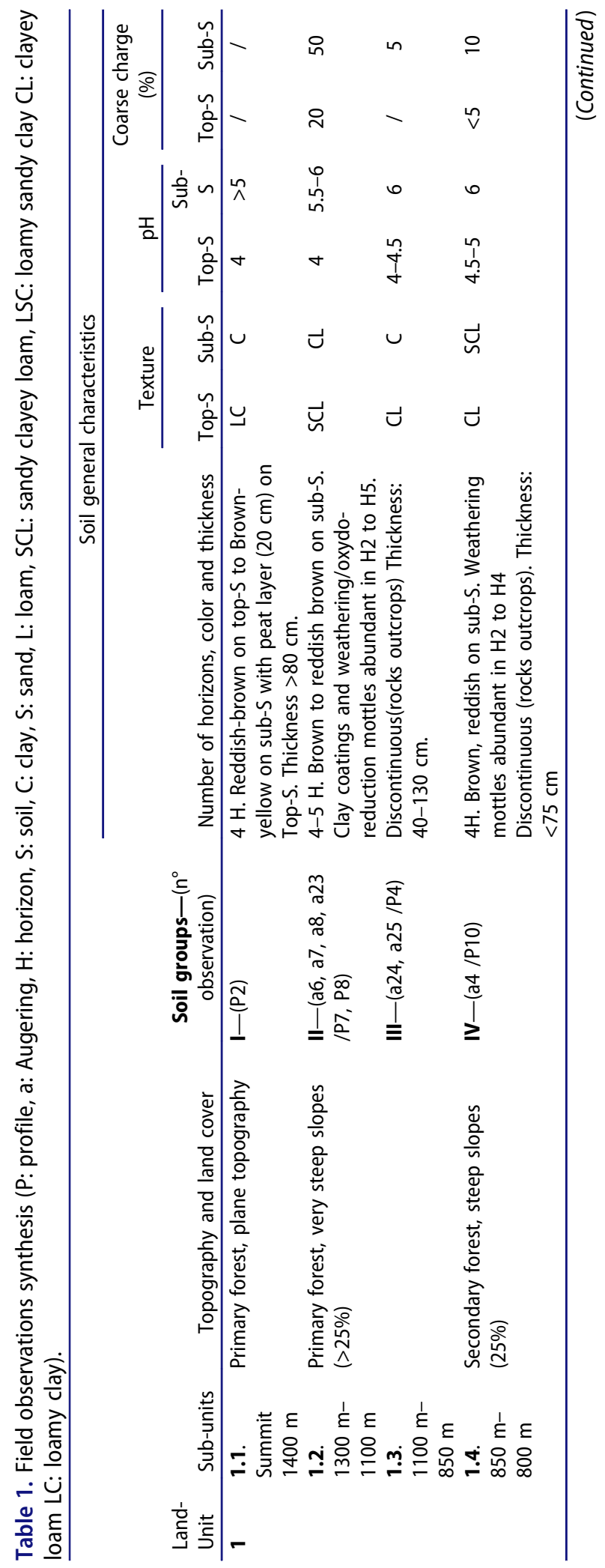




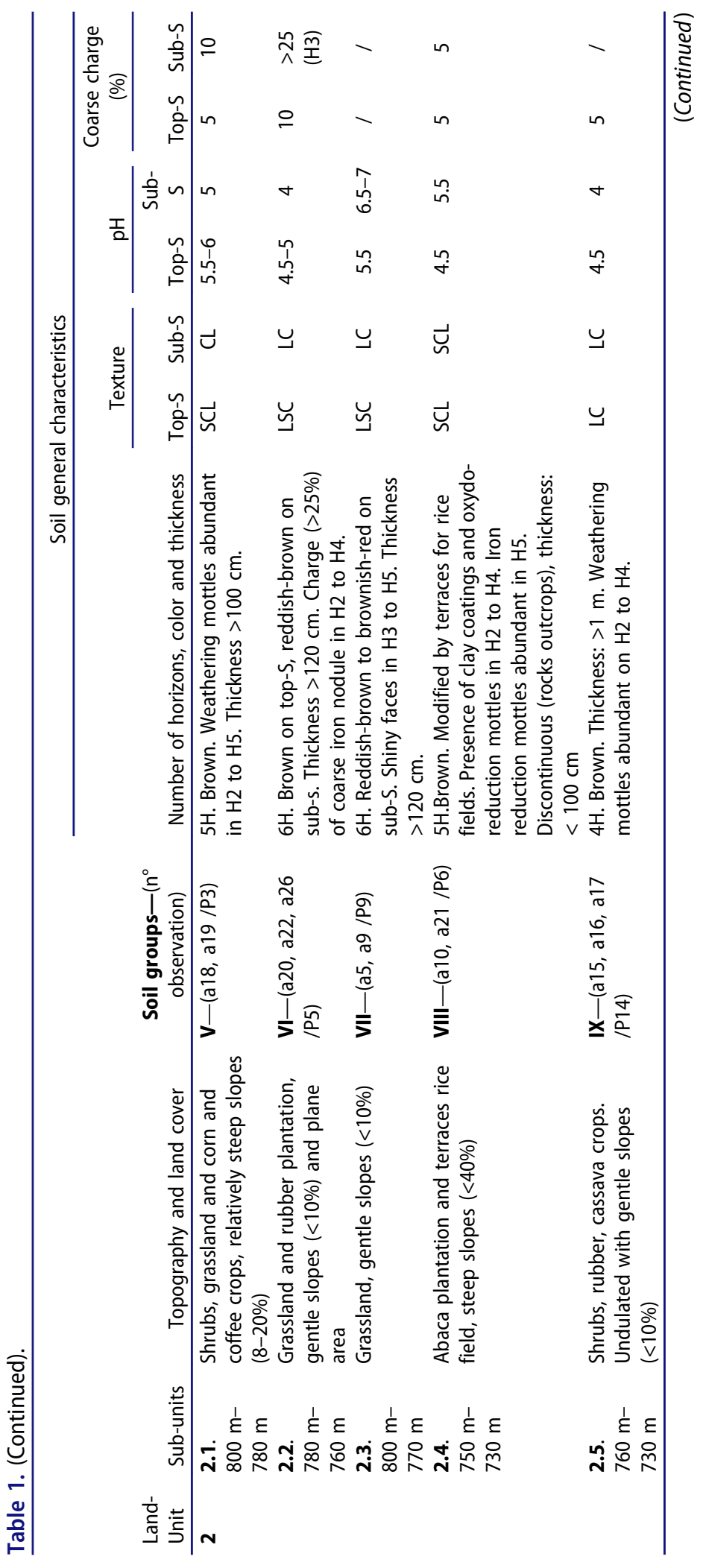




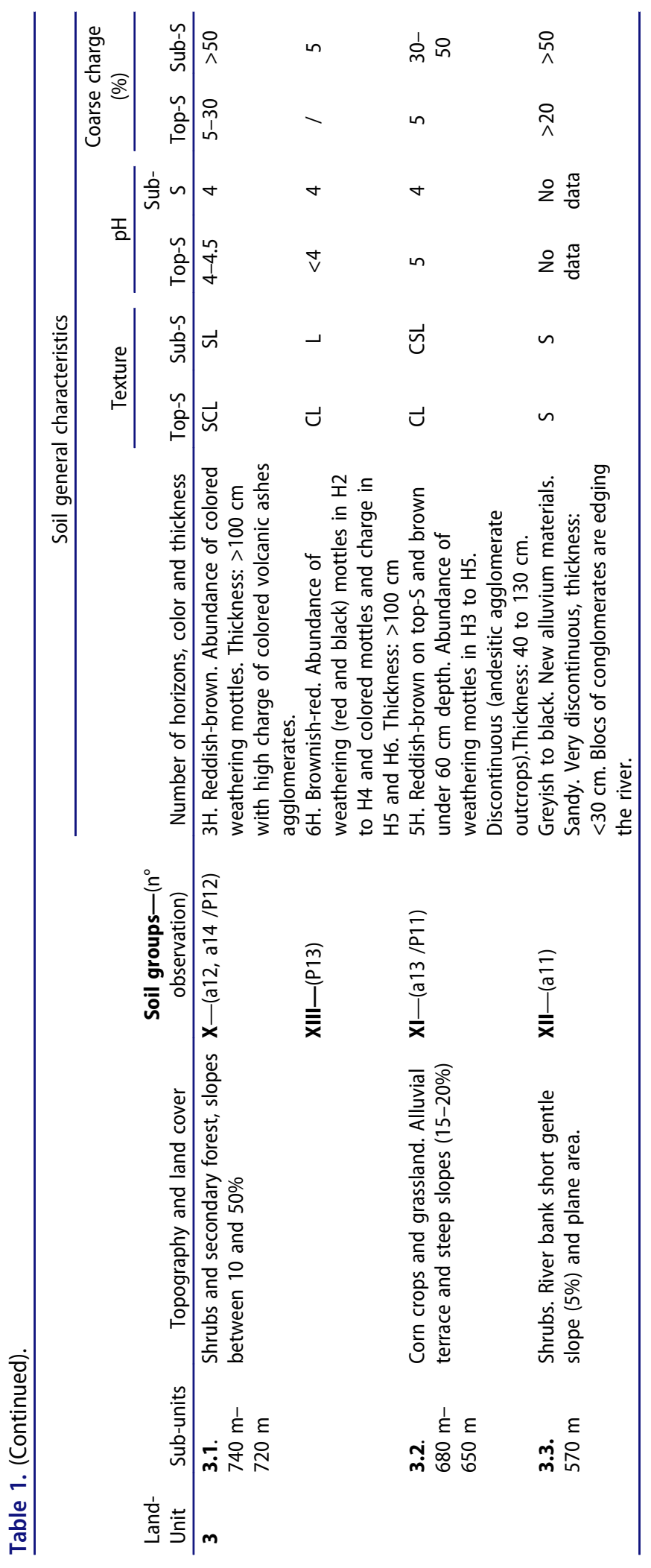


Analytical data confirm SG identified by field observations. Apart from some exceptions, there is a relative homogeneity in each soil group on the one hand and distinction between them in terms of chemical components measured on the other hand. The observed value ranges give general features of each soil group in terms of chemical properties. Most of the soils present a relatively high content in $\mathrm{Mg}(\mathrm{Mg}$ coming from ferromagnesium minerals present in primary rock).

Soil groups classification according to scientific criteria: WRB 2006. According to the panel of data needed to classify soil with WRB classification (FAO 2006a), only soils observed through a soil pit were classified. As an exception soil group XII (Table 1) is classified based on an augering. Among soil profiles observed, 12 profiles were classified based on $\mathrm{pH}$ measurements and field observations, but the 13th soil group was unclassifiable. The main soil classes identified are Acrisol, Cambisol, Ferralsols and Nitisols. An Acric horizon is related to Acrisol or Alisol depending on the type of clay. The choice of Acrisol was based mainly on the very low $\mathrm{pH}$ measured in the field.

\section{Vernacular soil typologies}

The first result revealed by discussions with farmers is that there is not a single unique typology but several. Even in this small village different types of knowledge on soils coexist. History and migration profiles of individual household appear to be determining elements of farmers' soil knowledge. In the two distinctive typologies presented here (Table 2), some soil types belong to both while others only appear in one. Soil types are described by their location (e.g. proximity of streams, and slope), their physical characteristics; topsoil color, feel to the touch, resistance to water erosion, presence or absence of rocks, moisture, heat or coldness and their relation with vegetation (cropped or spontaneous). Only the most typical characteristics of each soil type are described by farmers. It appears that not all farmers use soil names to characterize their own soils. To describe their land, they distinguish soils mainly by their color and not necessarily by a defined soil type. Red, yellow, brown, and black are the most often cited colors. Farmers' households interviewed describe between one and four different soil types within their land.

In the local perception of soil heterogeneity, vegetation, and cropping compatibility appear as essential elements. Their choices in term of crop-soil associations are explained as a way to avoid exhausting soils by taking into account a soil's sensitivity. For instance, some farmers mentioned the risk to change a soil type into a poorer one if the appropriate soil-crop association is not respected. They also use the crops growing well without fertilizer in each soil type as an indicator of soil fertility. Binukid typology also includes noncultivated soils, 


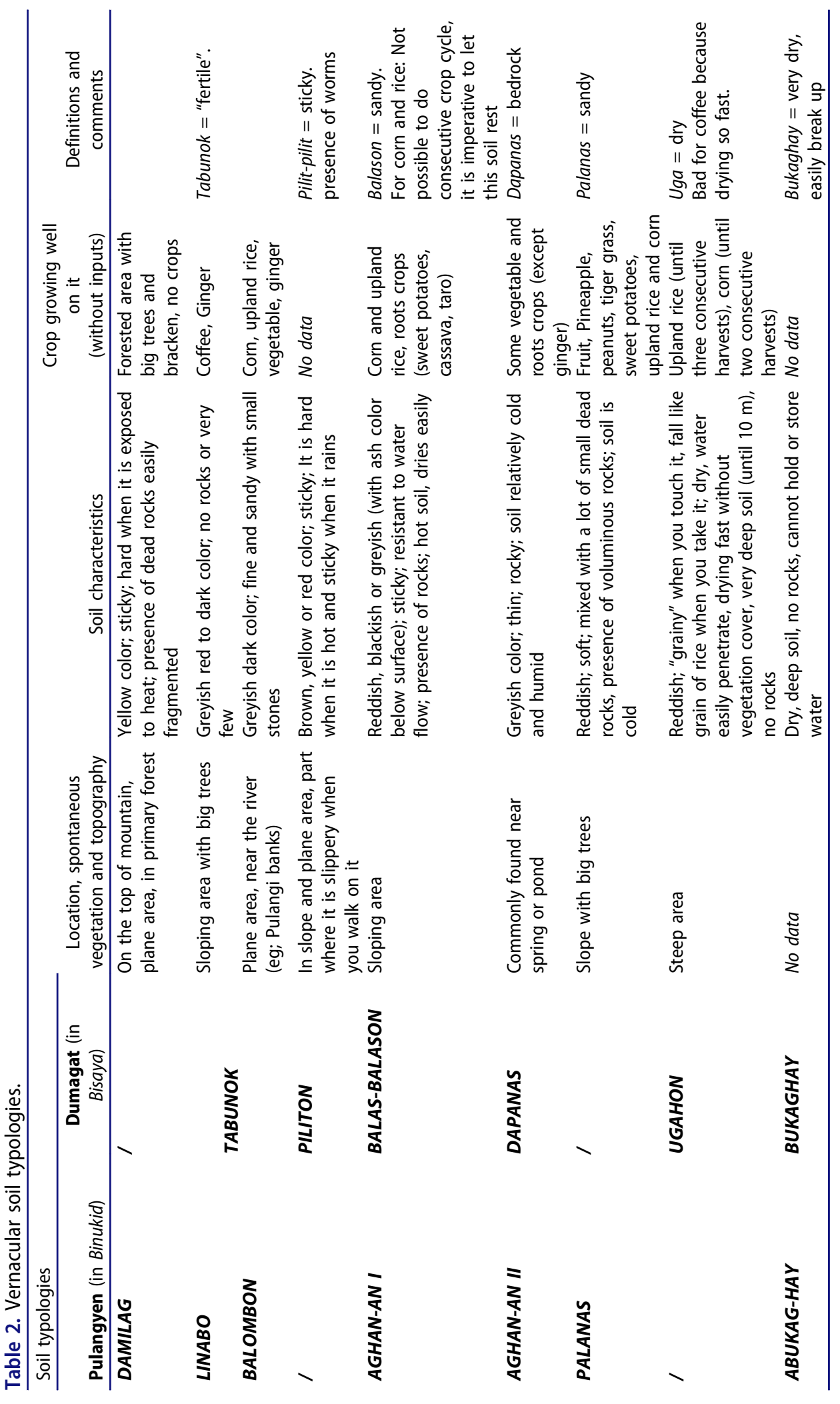


probably because they have a more familiar daily interaction with forested areas and they have been living in the area for longer than the migrants.

\section{Relations between vernacular typologies and soil groups}

We linked vernacular typologies and soil groups based on locally described and personally observed commonalities. This correlation results from hypotheses because it was not possible, in the timeframe of this study, to confirm it with local people. These hypotheses are based on obvious criteria available for both soil descriptions as location, natural vegetation, topsoil color, texture, depth, and rocks presence or absence. In this way, we were able to relate Damilag to soil group I; Linabo/Tabunok to soil groups II, III, V, and VIII; Agan-an I/Balasbalason to soil groups IV and XI; Piliton to soil group VII; Palanas to soil groups $\mathrm{X}$ and XIII; and Balombon/Tabunok to soil groups XII.

Soil groups and vernacular typologies do not perfectly match. Two soil groups (IV and IX) do not correspond to any vernacular soil type (VST) and three VST (Agan-an II/Dapanas, -/Ugahon, and Abukag-hay) were not connected to soil groups.

\section{Discussion: Plurality of soil knowledge between confrontation and complementarity}

In this study it clearly appears that there are many ways to perceive, describe, and explain soil heterogeneity. The discussion below aims at giving a critical analysis of the plurality of knowledge involved in this study: its characteristics, particularities, similarities, and dissonances.

The triggering factor of the ethnopedological dimension of this study was the attempt to feedback results from the geomorphopedological and analytical approach to local farmers. Explaining the geomorphopedological approach was possible because it is based on the local environment. Graphical representation (toposequences) was not familiar for local people but after discussion, a common understanding of soil heterogeneity identification based on field observation was achieved. It was much more difficult to explain the meaning and the practical interest of laboratory quantitative results and the correspondence with WRB classification. These types of data are related to the invisible (abstract) dimension of soil characteristics and/or are disconnected from the local context. Is it nevertheless possible to work together when knowledge schemes are so distinct, and knowledge so disconnected from its practical dimension? 


\section{Precautions in terms of linking different kind of soil typologies: Methodological perspectives}

\section{Understanding differences}

Different manners to approach soil heterogeneity are associated with different soil knowledge systems. To differentiate these three soil assortments, we distinguish three terms in this paper: VST based on a local soil knowledge system, SG based on fieldwork observations, and soil classes (SC) based on a scientific knowledge system.

The differences between those soil assortments (Table 3) can be explained mainly by the context in which knowledge is constructed and the purposes of that knowledge. VST are singular in terms of context and knowledge; SG are singular in terms of local context but constructed with a generalizable knowledge approach, and SC are constructed within a general context (worldwide) and with standardized knowledge.

It indicates the need for caution when formalizing the comparison and correspondences between them (Krasilnikov and Tabor 2003).

VST can be seen as the result of a long back and forth process between soil observation and soil use. Some vernacular criteria to describe soils are specific to each farmer while others are shared by several farmers. Knowledge on soil heterogeneity and the way to take it into account in farming practices makes sense in the particular socioecological context. Local people explain their soil typologies in relation with cropping practices, crop choice or local topography, and understand soil dynamics in relation with their livelihood and cosmology. There is no sense in attempting to standardize their classification system, since local people do not need to compare their soils with soils located elsewhere. Their theoretical schemes are not based on abstract entities defined by external categories as used in soil sciences. The singularity of this kind of soil knowledge is exemplified by the fact that at least two vernacular typologies were present in the same village, related to people from different origins. Furthermore, each farmer has his or her own knowledge on soil concerning their land.

SG result from field observation in a topographical organization of the land. Identification of SG is based on similarities observed (by augering and soil profile description). This soil assortment results from a spatially and temporally limited survey, fixing realities-like photography_of a moving situation. Observation criteria used for soil profile characterization need to be comparable to other contexts. For this reason they are strictly codified. This assortment aims firstly to describe local soil heterogeneity and, secondly, to relate it to other classifications in order to connect available knowledge on soils types identified. SG are associated with the researcher's knowledge system emerging from a fieldwork process in which the researcher is influenced by the local ecological context and sociocultural realities. 
The SC (WRB classes in the case of this study) result from the compilation and systematization of international soil science knowledge. Definition of SC is based on standardized criteria and organized in a classification system. Criteria are established to be objective, standardized, and generalizable. Classifying soil types in SC implies the realization of a specific set of laboratory analyses not necessarily needed for other purposes (particle size distribution, clay mineralogy, $\mathrm{CEC}$ at $\mathrm{pH} 7$, extractable Fe, etc.). The usefulness of WRB classification for farm advice is limited because of difficulties in applying general advice on particular situations. Studies dedicated to refine WRB classification complete the description and understanding of soil's worldwide heterogeneity, but the construction process of this systematized knowledge is not embedded in a farming perspective. It needs to be adapted when applying agronomical advice related to each SC. The WRB classification system is associated with a scientific knowledge system characterized as theoretical, specialized, impersonalized, and abstract (Villoro 1982).

\section{A contextualized comparison}

SG, because they are on the one hand based on local environment (vegetation, rocks, and topography) and on the other hand related to more general knowledge on soil, can bridge the gap between local and scientific perceptions in terms of common understanding of soil heterogeneity. In the perspective of sharing knowledge, geomorphopedological observation criteria can be relatively easily related to those used by local people.

In Table 3 we present a comparison between VST, SG, and SC by using SG as contextualized articulation. It is possible to look for correspondences between VST and WRB SC only through local field-based criteria (SG). Practically, VST were linked to SG based on obvious descriptive criteria while SG were linked to WRB classification based on diagnostic horizons and physicochemical properties.

Using SG as an articulating category between VST and SC avoids assimilating VST to SC by using only analytical criteria. We looked for correspondences only for VST for which we found a relation with SG. Based on this, three VST seem to correspond to WRB soil class as Linabo/Tabunok corresponds to Acrisol, Piliton to Nitisol and Balombon/Tabunok to Arenosol. Conversely, Cambisols cover a plurality of VST (Damilag, Agan-an I/Balas-balason and Palanas) and Ferralsol does not have an equivalent in vernacular soil typologies.

Though correspondences can be found, dissonances may teach us more. It is possible to find correspondences but it is crucial to keep in mind the differences and to be conscious about the purpose of establishing correspondences. Vernacular typologies bring many more details about local environment particularities than WRB classes. For instance, the Cambisol soil class, mainly based on morphological criteria, covers soils with very distinct physicochemical properties. Therefore this category is not relevant in terms of local soil use. 
Table 3. Typologies comparison.

\begin{tabular}{|c|c|c|c|}
\hline & Vernacular typologies & $\begin{array}{c}\text { Soils groups based on } \\
\text { geomorphopedological } \\
\text { fieldwork }\end{array}$ & $\begin{array}{c}\text { WRB } \\
\text { classification }\end{array}$ \\
\hline $\begin{array}{l}\text { Learning process of } \\
\text { knowledge } \\
\text { construction }\end{array}$ & $\begin{array}{l}\text { Ecosystem appropriation, } \\
\text { by dynamic daily } \\
\text { interaction. Back and } \\
\text { forth between uses and } \\
\text { observations. }\end{array}$ & $\begin{array}{l}\text { Geomorphopedological } \\
\text { identification, fieldwork } \\
\text { observations. Interaction } \\
\text { with environment limited } \\
\text { in time. }\end{array}$ & $\begin{array}{l}\text { Compilation and } \\
\text { systematization of } \\
\text { international soil } \\
\text { scientist } \\
\text { knowledge. }\end{array}$ \\
\hline Purposes & $\begin{array}{l}\text { Cropping practices and } \\
\text { others soils uses. To } \\
\text { practice the best soil-crop } \\
\text { association. }\end{array}$ & $\begin{array}{l}\text { Soil study to characterize } \\
\text { soil heterogeneity and/or } \\
\text { give particular agronomical } \\
\text { advices to farmers }\end{array}$ & $\begin{array}{l}\text { Classify soils, } \\
\text { standardize soil } \\
\text { knowledge, and } \\
\text { systematize } \\
\text { agronomical } \\
\text { advices }\end{array}$ \\
\hline Context & Local environment & Local environment & $\begin{array}{l}\text { Worldwide } \\
\text { environment }\end{array}$ \\
\hline Soil description & $\begin{array}{l}\text { Based only on topsoil and } \\
\text { visible characteristics } \\
\text { directly connected with } \\
\text { crop health. }\end{array}$ & $\begin{array}{l}\text { Based on soil entire profile, } \\
\text { field observations and } \\
\text { chemical analysis }\end{array}$ & $\begin{array}{l}\text { Based on } \\
\text { diagnostic horizon, } \\
\text { field observations } \\
\text { and chemical } \\
\text { analysis }\end{array}$ \\
\hline Soil Knowledge & $\begin{array}{l}\text { Local: singular, no need to } \\
\text { be compared }\end{array}$ & $\begin{array}{l}\text { Field based scientific: } \\
\text { singular but generalizable }\end{array}$ & $\begin{array}{l}\text { Scientific: } \\
\text { Standardized }\end{array}$ \\
\hline Soils types & $\begin{array}{l}\text { Vernacular soil types } \\
\text { (Pulangyen/Dumagat) }\end{array}$ & Soil groups & WRB \\
\hline $\begin{array}{l}\text { Soils types } \\
\text { correspondences and } \\
\text { dissonances }\end{array}$ & $\begin{array}{l}\text { Damilag/- } \\
\text { Linabo/Tabunok } \\
\text { Linabo/Tabunok } \\
\text { Agan-an I/Balas- } \\
\text { balason } \\
\text { Linabo/Tabunok } \\
\text { No correspondence } \\
\text { /Piliton } \\
\text { Linabo/Tabunok } \\
\text { No correspondence } \\
\text { Palanas } \\
\text { Agan-an I/Balas- } \\
\text { balason } \\
\text { Balombon/Tabunok } \\
\text { Palanas ?' } \\
\text { Agan-an II/Dapanas } \\
\text {-/Ugahon } \\
\text { Abukag-hay }\end{array}$ & $\begin{array}{l}\text { I } \\
\text { II } \\
\text { III } \\
\text { IV } \\
\text { V } \\
\text { VI } \\
\text { VII } \\
\text { VIII } \\
\text { IX } \\
\text { X } \\
\text { XI } \\
\text { XII } \\
\text { XIII } \\
\text { No correspondence } \\
\text { No correspondence } \\
\text { No correspondence }\end{array}$ & $\begin{array}{l}\text { Cambisol } \\
\text { Acrisol } \\
\text { Acrisol } \\
\text { Cambisol } \\
\text { Acrisol } \\
\text { Ferralsol } \\
\text { Nitisol } \\
\text { Acrisol } \\
\text { Ferralsol } \\
\text { Cambisol } \\
\text { Cambisol } \\
\text { Arenosol } \\
\text { Unclassified } \\
\text { / } \\
\text { / }\end{array}$ \\
\hline
\end{tabular}

${ }^{1}$ This association very uncertain.

\section{Finding practical bridges for collaborative soil studies}

For practical farming purposes, this study shows that it is not necessarily relevant to compare vernacular soil typologies with standardized classification (WRB or others national or international classifications). There is no practical sense to operate assimilation between those because they do not have the same finalities; this operation would amputate local knowledge of its contextual content and practice-based origin (Agrawal 2002). Farming advice could be based directly on 
vernacular soil typologies. A "technical" description of VST can bring complementary information to local farmers "soil description." In this sense, SG emerging from a geomorphopedological approach can be more than an intermediary means to facilitate dialogue between distinctive soil assortments; these can also be a useful tool to work together with farmers in collaborative soil and farming studies. They are a base for elaborate common language between scientists and farmers in terms of soil knowledge because they are understandable by both-by farmers, because SG are locally situated and field-based descriptions, and by scientists, because SG are based on more formalized criteria than VST (and not only on soils uses and daily interactions).

To be consistent, correspondence between VST and SG should be established and confirmed by farmers, while observing soils with them.

Correspondence established between VST and SG is valuable only for spatial points where soil observations were done, since it is not possible to do spatial extrapolation (in a mapping process for instance) without repeating more augerings and soil observations. These localized correspondences allow working together to achieve participatory soil maps. Ideally the geomorphopedological and ethnopedological approach should be constructed together from the onset.

\section{Which soil knowledge for which agro-socio-ecosystem? Epistemological perspectives}

Knowing local soil heterogeneity by daily observation is essential in guiding decisions on which crop to grow and on fertility assessment, especially in a context with limited access to inputs (organics or chemical). Local people use their practical knowledge to establish adequate cropping systems (Saito et al. 2006). What happens when the western scientific knowledge-paradigm bypasses this continuity between knowledge and practice?

Part of scientific knowledge on soil (pedogenetic and pedological identification) is disconnected from practical realities because it is dedicated mostly to detailed description of soil types and pedogenesis dynamics. Another important part, like chemical fertility assessment and agronomical advice, is related to soil use and cropping practices. This scientific knowledge is constructed in a specific modern agro-industrial context and does not have practical relevance in every situation.

In this study it appears clearly that if only standardized quantitative criteria are used (as WRB and analytical laboratory results), local farmers cannot take advantage of the results of the study. Moreover, practical advice coming from laboratory analyses is mainly adapted to high external input agriculture and of questionable relevance to organic or traditional farming.

Bridging local soil knowledge and scientific soil knowledge with the aim of improving soil heterogeneity understanding and local sustainable soils use requires critical thinking about how knowledge is constructed. This bridging 
exercise also calls for identifying the similarities, incompatibilities, and possible complementarities between those different knowledge systems.

Which kind of knowledge can be used to ensure the adequacy of soil studies for both the practical needs of local people and for scientific purposes? What can be done when scientific purposes and the needs of local people are often divergent? In trying to answer these questions, we cannot get around the domination/subordination relationship between the western science paradigm and local knowledge, and within any knowledge system (for instance gender relationships) (Cashman 1991; WinklerPrins 1999). Without the recognition and the thwarting of this power relationship, work on real synergies is not conceivable and negative prejudice on local knowledge will occur again. As Barrera-Bassols (2010, p.78) put it: "the full recognition of western science as a limited and contextual knowledge system is basic for the implementation of a synergetic approach".

In particular, the cosmological dimension of local ecological knowledge systems (Toledo and Barrera-Bassols 2008) must not be neglected when studying soil at the local level and confronting local and scientific perceptions of soil. In this study, indigenous people interviewed have a complex perception of soil related to natural and spiritual realities. The spiritual aspect is directly connected with cropping practices by the intermediate of guardian spirits whose presence implies respect and using soil without exhausting it. This cosmological vision contrasts with the rational vision of modern science that sees soils as an objectively defined entity described by chemical and physical components and by a series of functions such as productivity and water retention.

If industrial agriculture can neglect farmers' knowledge it is partly because industrialization has produced artificial environments (based on external inputs like fertilizers and fossil fuels) that can be managed and "controlled" with standardized procedures. Today, human and ecological damage generated by this homogenization of the agricultural landscape and related practices become clearer. There is a need to elaborate alternative farming pathways that are more considerate of ecological and human dimensions. In this context, farmers' knowledge presented here, coming from a non-industrial context, can be an important source of inspiration. We can hope that a greater interest is going to be given to experiential knowledge based on trial and error and emerging from daily interaction with complex natural phenomena and uncertainty. Farmers can learn about modern sciences but it does not mean that they should abandon their own knowledge on soil, which is often better adapted to their local context and intrinsically linked with their way of life.

Vernacular knowledge is dynamic, interacting with permanent farming experimentation. In this sense, vernacular typologies presented here are already "obsolete" because agricultural systems are rapidly changing in this region. This does not reduce the importance of focusing on them. Conversely, giving attention to local knowledge in weakened communities can help strengthen local skills and endogenous farming improvement adapted to local agro-socio-ecosystem 
(Guzman et al. 1996; Van Der Ploeg et al. 2000). In the present context, where farmers are faced with the continuous emergence of new technologies, if they acquire sufficient skills to understand the meaning of technical and scientific knowledge, they can develop a critical view of them.

This implies the creation of a dialogue between scientists and farmers in order to, on one hand, transmit sufficient skills to local farmers to understand the western-scientific paradigm and on the other hand to push soil scientists to base their soil surveys on local soil knowledge in order to orient scientific results in a local, practical perspective.

\section{Conclusion}

The Philippines upland indigenous context, a stronghold of indigenous culture and cosmovision, provides an opportunity to contrast local peoples' and researcher's realities. Such a situation is thought provoking and highlights practical and theoretical issues that are less visible in a western context. However, we believe these issues should be dealt with in every soil study relating to farming aspects.

These methodological and epistemological issues call for the emergence of co-constructed and locally relevant knowledge that allows a better fitting of soil use with each context.

It appears that, from a local farming point of view, there is little practical interest in linking VST with scientific soil categories. Furthermore, this linkage established only for exogenous modernization purposes can distort the practical relevance of local knowledge and tend to become "knowledge grabbing".

However, in a globalized context in which farmers are faced with the pressures of modernization, the collaboration with scientists engaged in working in an endogenous perspective can strengthen and assist farmers' initiatives and farming experimentations.

The "ethnopedological integral approach" brings very interesting thoughts and background to this perspective. It stresses the importance of finding and enhancing synergies between scientific and local approaches in an endogenous perspective. As described by Barrera-Bassols (2010, p.83-84) this approach aims to "link soil and land wisdom and knowledge to promote feasible and sustainable local endogenous development in an interdisciplinary perspective. By analyzing historical, ecological, economic and political factors and changes at the local level and with full participation of the local actors, this contextual approach could gain strength through co-validating and implementing in a creative way both, scientific and the empirical sources of information."

In this paper, some tracks of possible synergies were envisaged as a contribution to that epistemological and methodological research. Studying vernacular soil typologies in a participatory way is an essential step for learning about local contexts and to elaborate a common language in order to improve collaboration 
between local farmers and soil scientists. In each particular context the plurality of soil knowledge should be taken into account and used in the best complementary manner.

We demonstrated that local knowledge proceeds from various interactions revealing the complexity of local context. We also showed that it is temporally dynamic whereas scientific knowledge applied in a local context is fixed in time and specialized. Perception and description of soil heterogeneity differ mainly in the construction process and in the purposes of knowledge. Since farmers' soil knowledge is linked with specific cropping practices and livelihoods, it is crucial to take into account the sociocultural dimension of farming to avoid the erosion of cultural and biological diversity on the planet.

Building practical knowledge in agriculture at the farm and local levels should be prioritized in order to get over the divide between scientists and farmers and to facilitate appropriation of study results by farmers. This quest of synergies is not only a methodological issue; it supposes a change in the way of doing research and accepting that the "western" vision is merely one vision among others.

\section{ORCID}

Lola Richelle (D) http://orcid.org/0000-0002-1098-8724

François Mialhe (1) http://orcid.org/0000-0002-5845-895X

Nicolas Dendoncker (1) http://orcid.org/0000-0001-9129-9025

\section{References}

Agrawal, A. 1995. Dismantling the divide between indigenous and scientific knowledge. Development and Change 26:413-39. doi:10.1111/dech.1995.26.issue-3.

Agrawal, A. 2002. Indigenous knowledge and the politics of classification. International Social Science Journal 54:287-97. doi:10.1111/issj.2002.54.issue-173.

Alcasid, J. R., and N. Godofredo. 1995. General soil map of the Philippines, sheet 3. [On line]. Manila: Department of Agriculture. Bureau of Soils and Water Management (BSWN). http:// eusoils.jrc.ec.europa.eu/esdb_archive/EuDASM/asia/lists/cph.htm (accessed august 2010).

Anonym. 2005. Duma. A Decade of engagement in Bendum. Manila: ESSC.

Barrera-Bassols, N. 2010. Landscape, soils and cultures. Worldwide and regional perspectives. Saarbrücken, Germany: Lambert Academic Publishing.

Barrera-Bassols, N., and J. A. Zinck. 2003. Ethnopedology: A worldwide view on the soil knowledge of local people. Geoderma 111:171-95. doi:10.1016/S0016-7061(02)00263-X.

Barrera-Bassols, N., J. A. Zinck, and E. Van Ranst. 2006. Symbolism, knowledge and management of soil and land resources in indigenous communities: Ethnopedology at global, regional and local scales. Catena 65:118-37. doi:10.1016/j.catena.2005.11.001.

Bendum Tribal Council (Assisted by ESSC). 2002. Ancestral domains sustainable development and protection plan, bukid-non-pulangiyen tribe. Malaybalay.

Bock, L. 1994. Analyse des sols et gestion de l'espace. Plaidoyer pour leur cadrage géomorphopédologique dans les projets, expertises et services de conseil. Etude Et Gestion Des Sols 1:23-33. (in French). 
Bureau of Soils. 1985. The physical land resources of the bukidnon province, (Land evaluation project). Manila: Ministry of Agriculture and Food, Region 10.

Cashman, K. 1991. Systems of knowledge as systems of domination: The limitations of established meaning. Agriculture and Human Values 8(1-2):49-58. doi:10.1007/ BF01579656.

Colinet, G., K. Koulos, W. Bozhi, L. Yongmei, D. Lacroix, S. Youbo, J. Chapelle, M. A. Fullen, T. Hocking, and L. Bock. 2011. Agro-pedological assessment of the traditional yuanyang rice terraces of Yunnan Province, China. Journal of Resources and Ecology 2(4):353-61.

Delecour, F., and M. Kindermans. 1980. Manuel de description des sols. Gembloux, Belgium: F.S.A.Gx.; Service de la Science du sol, 118 (in French).

ESSC. 2010. Bendum catchment landuse 2005. (map). Malaybalay: ESSC.

FAO. 1975. Carte des sols du monde. Rome: FAO.

FAO. 2006a. World reference base for soil resources, 120. Rome: FAO.

FAO. 2006b. Guidelines for soil description. 4th ed., 84. Rome: FAO.

Guzman, G., A. Alonso, Y. Pouliquen, and E. Sevilla. 1996. Las metodologías participativas de investigación: Un aporte al desarrollo local endógeno. Agricultura Ecológica y Desarrollo Rural. Pamplona-Iruña: II Congreso de la Sociedad Española de Agricultura Ecológica.

Henquin, B., C. Avril, L. Bock, and L. Mathieu. 1991. Potentialités physiques et stratégies de mise en valeur du milieu dans le Haut Bassin du fleuve Gambie, Cas d'étude: Le village de Téliré. Annales De Gembloux, 97ème Année 4:277-91. (in French).

Howard, P. 1994. The confrontation of modern and traditional knowledge systems in development. Canadian Journal of Communication 19(2):189-208.

Karl, M., and C. S. R. Gaspard. 2000. The lumad's struggle in the face of globalization. Hipolito: Davao City (Philippine): Rommel Abb.

Krasilnikov, P. V., and J. A. Tabor. 2003. Perspectives on utilitarian ethnopedology. Geoderma 111:197-215. doi:10.1016/S0016-7061(02)00264-1.

Lawrence, K. E. 1995. Bendum. Socio-economic profile. 1994-1995. Manila: Environmental Research Division Manila Observatory.

Mariano, J. A. 1950. Soil map, Bukidnon province, Philippines. [On line]. Manila: Department of Agriculture and Natural Resources http://eusoils.jrc.ec.europa.eu/esdb_archive/ EuDASM/asia/lists/cph.htm (accessed August 2010).

Mariano, J. A. 1955. Soil survey of Bukidnon province, Philippines. [On line]. Manila: Department of Agriculture and Natural Resources. Bureau of soils. http://eusoils.jrc.ec. europa.eu/esdb_archive/EuDASM/asia/lists/cph.htm (accessed August 2010).

Niemeijer, D., and V. Mazzucato. 2003. Moving beyond indigenous soil taxonomies: Local theories of soils for sustainable development. Geoderma 111:403-24. doi:10.1016/S00167061(02)00274-4.

Payton, R. W., J. J. F. Barr, A. Martin, P. Sillitoe, J. F. Deckers, J. W. Gowing, N. Hatibu, S. B. Naseem, M. Tenywa, and M. I. Zuberi. 2003. Contrasting approaches to integrating indigenous knowledge about soils and scientific soil survey in East Africa and Bangladesh. Geoderma 111:355-86. doi:10.1016/S0016-7061(02)00272-0.

Pretty, J., B. Adams, F. Berkes, S. Ferreira De Athayde, N. Dudley, E. Hunn, L. Maffi, K. Milton, D. Rapport, P. Robbins, E. Sterling, S. Stolton, A. Tsing, E. Vintinner, and S. Pilgrim. 2009. The intersections of biological diversity and cultural diversity: Towards integration. Conservation and Society 7(2):100-12. doi:10.4103/0972-4923.58642.

Ramisch, J. J. 2014. 'They don't know what they are talking about': Learning from the dissonances in dialogue about soil fertility knowledge and experimental practice in western Kenya. Geoforum 55:120-32. doi:10.1016/j.geoforum.2014.05.009.

Rushemuka, N. P., R. A. Bizoza, J. G. Mowo, and L. Bock. 2014. Farmers' soil knowledge for effective participatory integrated watershed management in Rwanda: Toward soil-specific 
fertility management and farmers' judgmental fertilizer use. Agriculture, Ecosystems and Environment 183:145-59. doi:10.1016/j.agee.2013.10.020.

Saito, K., B. Linquist, B. Keobualapha, T. Shiraiwa, and T. Horie. 2006. Farmer's knowledge of soils in relation to cropping practices: A case study of farmers in upland rice based slashand-burn systems of northern Laos. Geoderma 136:64-74. doi:10.1016/j. geoderma.2006.02.003.

Shiva, V. 1993. Understanding the threats to biological and cultural diversity. Ontario, Canada: Center for international programs, University of Guelph.

Sillitoe, P. 1998. It's all in the mound: Fertility management under stationary shifting cultivation in the Papua New Guinea Highlands. Mountain Research and Development 18:123-34. doi:10.2307/3673968.

Stevenson, M. G. 1996. Indigenous knowledge in environmental assessment. Arctic 49 (3):278-91. doi:10.14430/arctic1203.

Toledo, V. M. 1991. El juego de la supervivencia. Un Manual Para La Investigación Etnoecologica en Latinoamérica. México: Centro de ecología, universidad nacional autónoma de México.

Toledo, V. M., and N. Barrera-Bassols. 2008. La memoria biocultural, la importancia ecologica de las sabidurias tradicionales. Barcelona: Icaria Editorial.

Van Der Ploeg, J. D., H. Renting, G. Brunori, K. Knickel, J. Mannion, T. Marsden, K. De Roest, E. Sevilla-Guzman, and F. Ventura. 2000. Rural development: From practices and policies towards theory. Sociologia Ruralis 40(4):391-408. doi:10.1111/soru.2000.40.issue-4.

Villoro, L. 1982. Creer, saber, conocer. Filosofía: Siglo Veintiuno Editores. México (in Spanish).

Walpole, P. 2002. Effects of land conversion on water and nutrient retention in tropical mountain environment, Mindanao, Philippines. London: King's College London.

Walpole, P., G. Braganza, J. Burtkenley Ong, G. J. Tengco, and E. Wijanco. 1993. Upland Philippine communities: Guardians of the final forest frontiers. Berkeley: Southeast Asia Sustainable Forest Managment Network.

Whitford, H. N. 1911. The forests of the Philippines, Part I. Manila: Department of the Interior Bureau of Forestry.

WinklerPrins, A. M. G. A. 1999. Local soil knowledge: A tool for sustainable land management. Society and Natural Resources 12:151-61. doi:10.1080/089419299279812. 
Copyright of Agroecology \& Sustainable Food Systems is the property of Taylor \& Francis Ltd and its content may not be copied or emailed to multiple sites or posted to a listserv without the copyright holder's express written permission. However, users may print, download, or email articles for individual use. 